\title{
Characterization and application of chicken eggshell as green adsorbents for removal of $\mathrm{H}_{2} \mathrm{~S}$ from wastewaters.
}

\author{
Omar Abed Habeeb ${ }^{1 *}$, Faizah Md Yasin ${ }^{2}$, Umar Abdulbaki Danhassan ${ }^{2}$ \\ $I^{*}$ (Department of Salah Aldine Refinery/ North Refinery Company /Baiji/Ministry of Oil of Iraq) \\ $I^{*}$ and 2 (Departmentof Chemical and Environmental Engineering/Universiti Putra, Malaysia.43400)
}

\begin{abstract}
Hydrogen sulfide is fatal to benthic aquatic lives as depletes the dissolved oxygen in their ecosystem. The present work evaluated on characterization and the application of chicken eggshell as green and economical adsorbents for the treatment of hydrogen sulfide from wastewaters. The grounded chicken eggshell were characterized into calcinate waste eggshell; activate carbon derived from wastes of eggshell (modified adsorbents) and eggshell without treatments (unmodified adsorbent). At the $250 \mathrm{mg} / \mathrm{l} \mathrm{concentration}$ of polluted water, the results showed that the calcinate waste eggshell had the highest adsorption capacity of $2.1 \mathrm{mgg}^{-1}$ and the equilibrium time of 250 minutes. The adsorption capacity of activate carbon derived from wastes of eggshell was $1.6 \mathrm{mgg}^{-1}$ and the equilibrium time of 350 minutes. The eggshell without treatments at of $0.55 \mathrm{mgg}^{-1}$ and the equilibrium times was 400 minutes. It is concluded that the chickens' eggshell are very useful green and economic adsorbents due to their availability and absence of any toxic and hazardous constituent's elements from all adsorbents. The calcinate modified been the most suitable followed by the activate carbon modified adsorbent. The grounded chicken eggshell without treatments was the least suitable for the removal of $\mathrm{H}_{2} \mathrm{~S}$ from wasters.
\end{abstract}

Keyword: adsorbents, hydrogen sulfide, chicken eggshells, activate carbon, calcinate

\section{Introduction}

Increments of waste generation have been the famous aftermath of industrial revolution, which has taken the significant attention of the science community on the toxicity of the toxic and hazardous wastes. Among these categories, the impact of dyes, Hydrogen sulfide $\left(\mathrm{H}_{2} \mathrm{~S}\right)$ phenols, and others heavy metals are under intensive research [5].

The petroleum refinery is one of the polluters, due to the presence of sulfur in their wastewaters. This happens when the distillate crude oil is processed into useful product; various wastes could dissolve from different units operations and later be transported into the wastewaters when not properly treated. The hazardous substance from this process is the hydrogen sulfide $\left(\mathrm{H}_{2} \mathrm{~S}\right)$.

However, the hydrogen sulfide is corrosive to metals and fatal to benthic aquatic lives by depletion of dissolved oxygen in their ecosystem [2]. A factor in the formation of acid rain which affect our environment. Therefore, prior treatment of pollutant is very important before been discharge into the water bodies for good quality environment. Since the water quality assessments is very important element of sustainable development [1].

Generally, the physical, chemical, and biological are traditional wastewater treatment processes. Most of these tradition treatment processes are non-economical for industrial wastewaters due the high concentration of their effluents. Among treatment process, adsorption has been the most prolific method due to its efficiency in reducing the concentration of dissolved organics in the effluents [7]. Many researches are working harder to develop various green and economical materials of wastewater treatment [4]. Owing to their biodegradability, non-toxicity, and abundantly available, the use of chicken waste eggshell as agricultural waste residues for adsorption could be essential[6].

Malik, [3] found that activated carbon from sawdust was very useful in the removal of dye from wastewater. Abdurrahman et al., [6] recommended that orange peels are very significant for treatment of the dye from textile wastewaters [5] found that some modified rice husk has shown a rapid uptake of $\mathrm{Cd}$ (II) in the aqueous solution, therefore very important in the removal of heavy metals of industrial wastewaters. Yamamoto et al.,[2] recommended that the oyster shell was very effective for the adsorption of hydrogen sulfide from pore water. The present study seeks to evaluate the use of chicken eggshell as green and economical adsorbents for the treatment of hydrogen sulfide from wastewaters.

\subsection{Characterization of grounded waste eggshell.}

\section{Materials and methods.}

The Eggshell samples for this study were washed with the deionized water to remove the impurities from the samples then dried at $105{ }^{\circ} \mathrm{C}$ in a hot air oven for 8 hours, and grounded with a blender, and vetted through a set of sieves of $0.25,0.3$ and $0.5 \mathrm{~mm}$ respectively. The sieved samples were separated into calcinated waste 
eggshell (ESC), activated carbon derived from wastes of eggshell (ESA) and eggshell without treatments (ESWT).

The ESC was calcite at temperatures ranging from 150 to $900{ }^{\circ} \mathrm{C}$, soaking time of 2 hours, a constant heating rate of $10^{\circ} \mathrm{Cmin}^{-1}$ with Nitrogen $\left(\mathrm{N}_{2}\right)$ flow rate of $30 \mathrm{STP}^{3} \mathrm{~min}^{-1}$ and Pyrolysed in a horizontal tubular reactor made of quartz in furnace carbolated, the results are shown in Table 1. The ESA was treated at temperatures ranging from 150 to $700{ }^{\circ} \mathrm{C}$, soaking time of 4hours, constant heating rate of $10^{\circ} \mathrm{C} \mathrm{min}{ }^{-1}$ with Nitrogen $\left(\mathrm{N}_{2}\right.$ ) flow of $30 \mathrm{STP} \mathrm{cm}^{3} \mathrm{~min}^{-1}$ and Pyrolysed in a horizontal tubular reactor made of quartz carbolated . The results components are shown in Table 2. The EWT was used directly without any further physical or chemical treatment.

\subsection{Adsorption experiment}

In this study the sour water samples were prepared using the standard laboratory preparation reaction between ferrous sulfide $(\mathrm{FeS})$ with $\mathrm{HCl}$ in a Kipp generator to produce $\left(\mathrm{H}_{2} \mathrm{~S}\right)$ which is then passed through distillated water. $\mathrm{FeS}(\mathrm{s})+2 \mathrm{HCl}(\mathrm{aq}) \rightarrow \mathrm{FeCl}_{2}(\mathrm{aq})+\mathrm{H}_{2} \mathrm{~S}(\mathrm{~g})$.

The pollutants concentration was initially measured. The adsorption was carried out by using $1 \mathrm{~g}$ each of CES , ACE , and EWT respectively, and placed in $250 \mathrm{~mL}$ of pollutant water in a flasks bottles. The $\mathrm{pH}$ of the samples solution were adjusted to neutral, and were shaken at $150 \mathrm{rpm}$ with electric shaker at $25{ }^{\circ} \mathrm{C}$ for 72 hours to test their adsorption capacities.

Subsequently, after screening the suspensions, the residual solution was used to measure the concentration of the adsorbent using the UV-vis spectrophotometer at $270 \mathrm{~nm}$. The standard calibration curve was used to get the final concentrations of the pollutants. The adsorption capacity of the pollutants was calculated by Equation below.

$$
q_{e}=\frac{V\left(C_{o}-C_{e}\right)}{m}
$$

where $\mathrm{V}$ is the volume of the solution (L), $\mathrm{m}$ is the amount of adsorbent $(\mathrm{g})$, and $\mathrm{C}_{\mathrm{o}}$ and $\mathrm{C}_{\mathrm{e}}$ are the initial and final concentrations in the pollutants, (qe) is adsorption

\section{Results}

Table 1. The compositions of calcination of grounded eggshell $\left(\mathrm{mg}^{-1} \mathrm{~g}^{-1}\right)$.

\begin{tabular}{crc}
\hline Element & Weight & Normal compound\% \\
\hline $\mathrm{C}$ & 2.56 & 2.56 \\
$\mathrm{O}$ & 53.99 & 53.99 \\
$\mathrm{Mg}$ & 1.66 & 1.66 \\
$\mathrm{P}$ & 2.15 & 2.15 \\
$\mathrm{~S}$ & 0.48 & 0.48 \\
$\mathrm{Ca}$ & 39.15 & 39.15 \\
Total & 100.00 & 100.00 \\
\hline
\end{tabular}

Table 2. The compositions of activated carbon derived from eggshell wastes ( $\left.\mathrm{mg} \mathrm{g}^{-1}\right)$

\begin{tabular}{ccc}
\hline Element & Weight \% & Normal Compound\% \\
\hline $\mathrm{C}$ & 8.18 & 8.18 \\
$\mathrm{O}$ & 65.09 & 65.09 \\
$\mathrm{Mg}$ & 0.36 & 0.36 \\
$\mathrm{Ca}$ & 26.37 & 26.37 \\
Total & 100.00 & 100.00 \\
\hline
\end{tabular}

Table 3. The compositions of grounded of eggshell without treatment $\left(\mathrm{mg}^{\mathrm{g}} \mathrm{g}^{-1}\right)$

\begin{tabular}{ccc}
\hline Element & Weight \% & Normal compound\% \\
\hline $\mathrm{C}$ & 24.36 & 24.36 \\
$\mathrm{O}$ & 56.27 & 56.27 \\
$\mathrm{Mg}$ & 0.33 & 0.33 \\
$\mathrm{~K}$ & 0.40 & 0.40 \\
$\mathrm{Ca}$ & 12.48 & 12.48 \\
$\mathrm{Mo}$ & 6.16 & 6.16 \\
Total & 100.00 & 100.00 \\
\hline
\end{tabular}



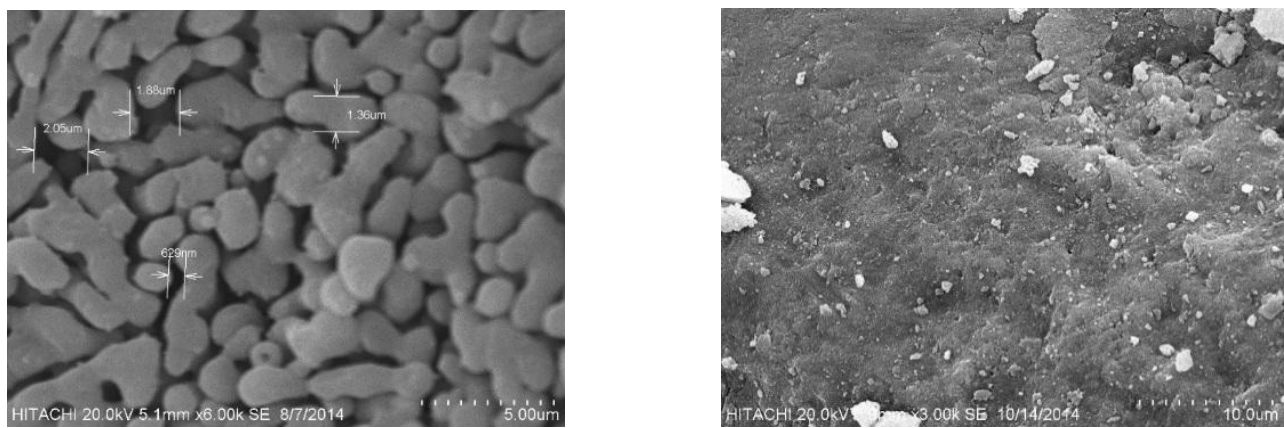

Figure 1. Porosity and surface area of ESC. Figure 2. Porosity and surface area of ESA

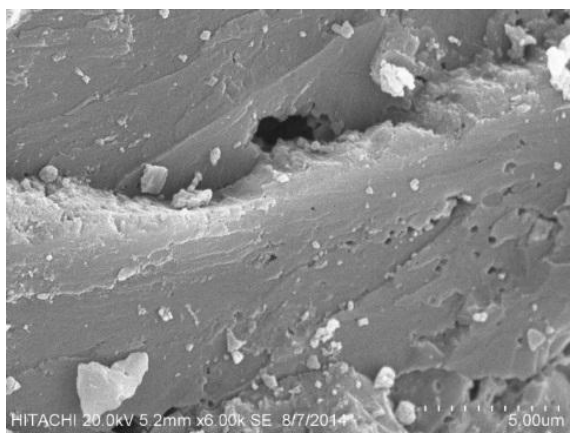

Figure 3. Porosity and surface area of ESW
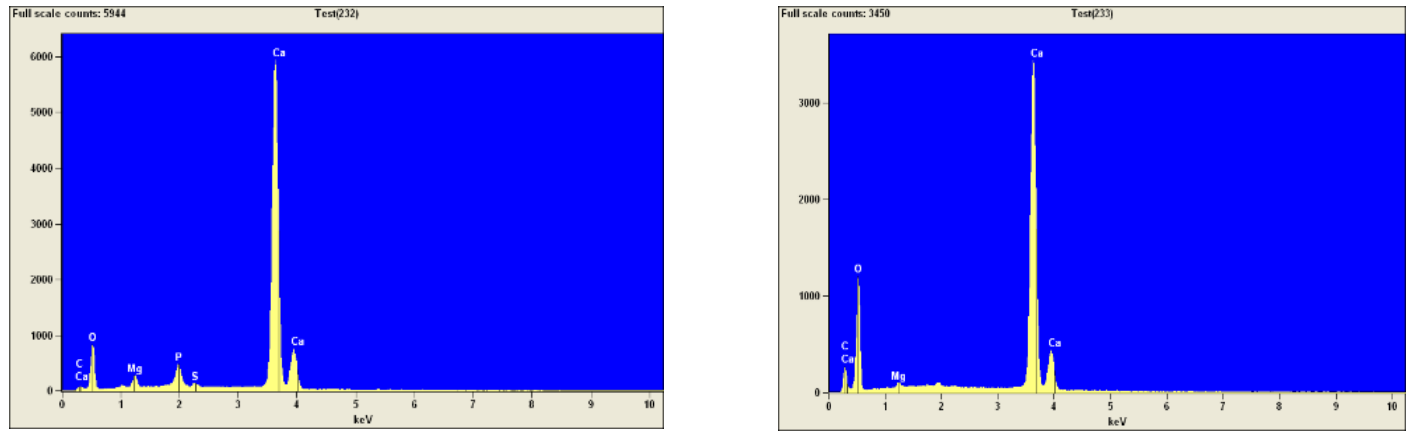

Figure 4. The chemical compositions of ESCFigure 5. The chemical compositions of ESA

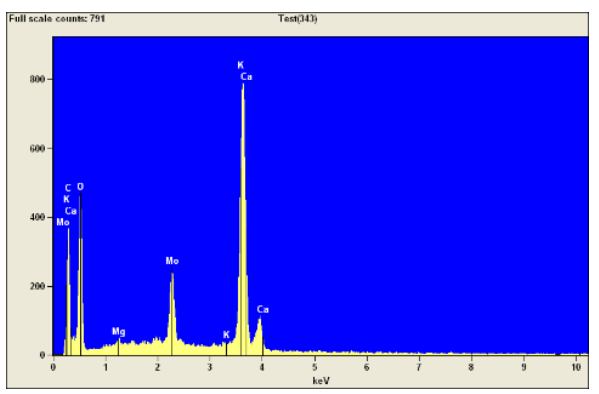

Figure 6. The chemical compositions of ESWT 


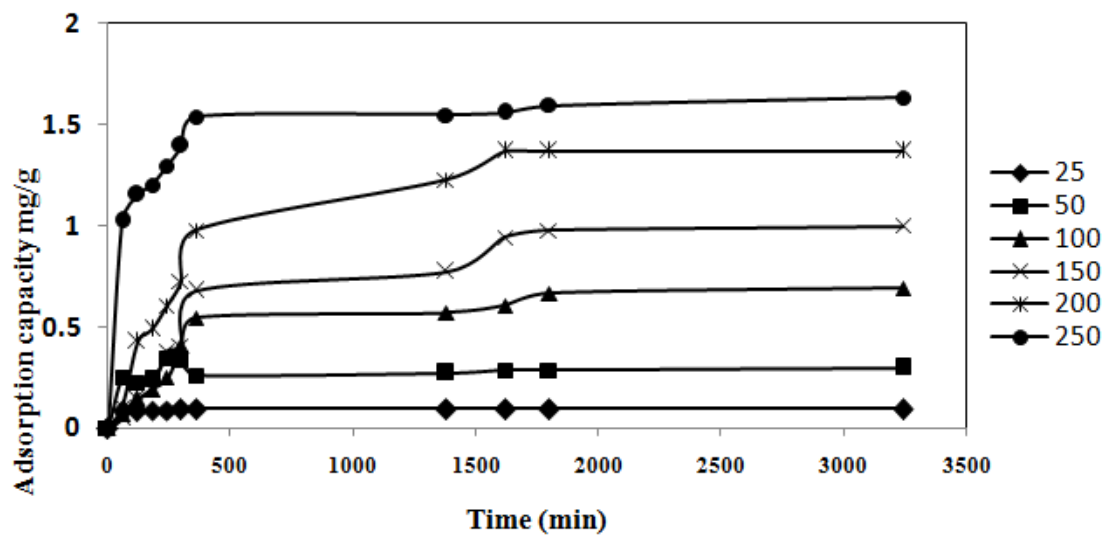

Figure 7. Effect of time on adsorption capacity by using ESC

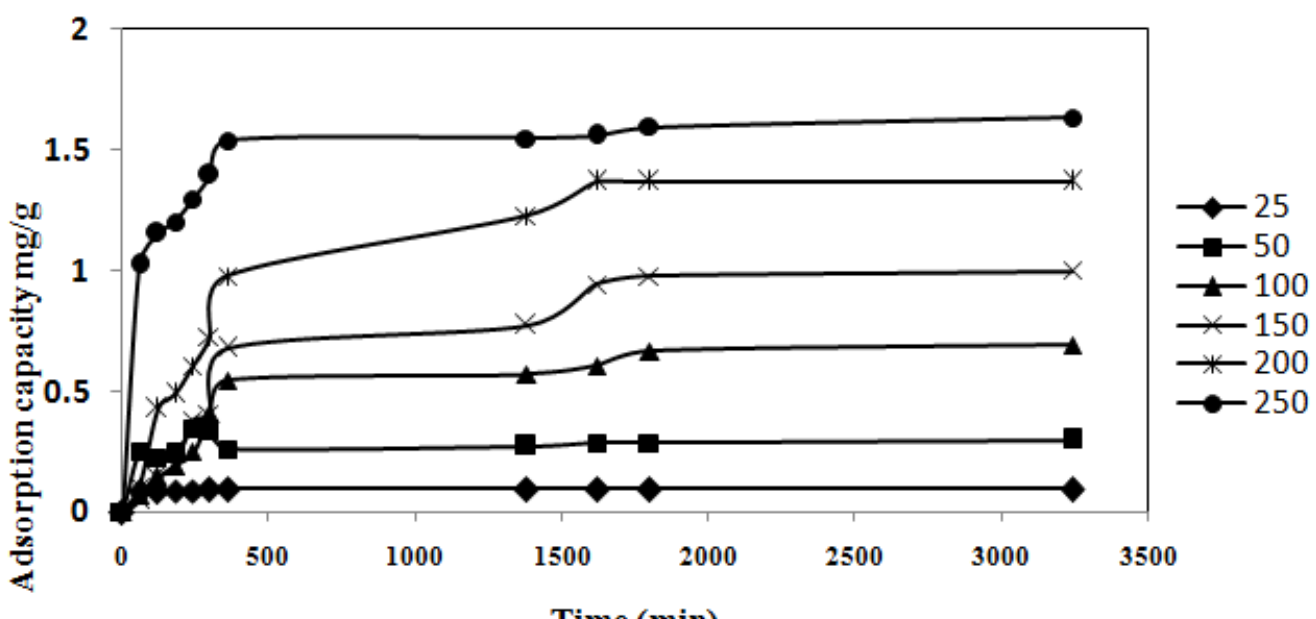

Time (min)

Figure 8. Effect of time in different concentration on adsorption capacity of ESA

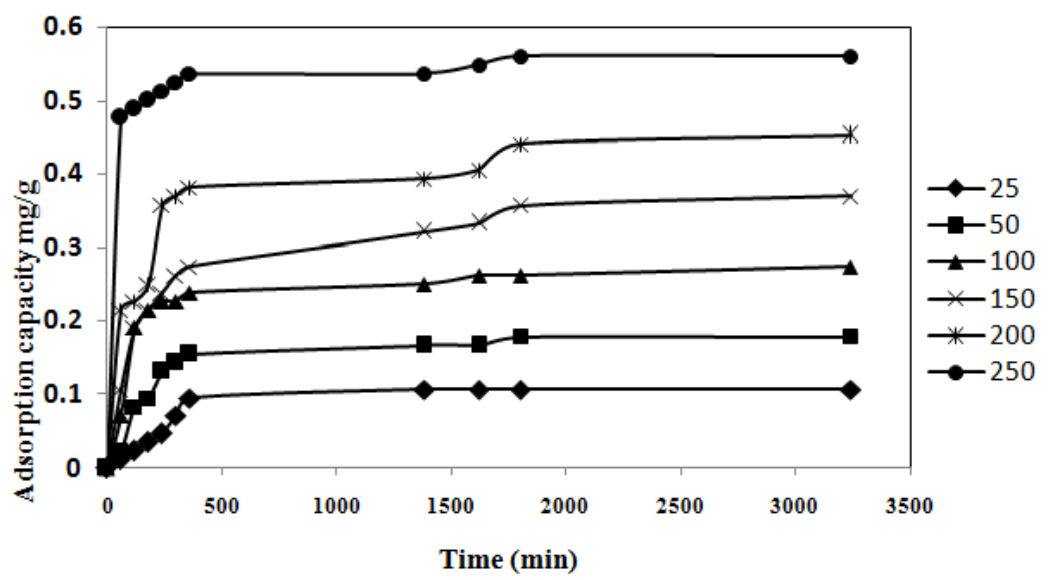

Figure 9. Effect of concentration on adsorption capacity by using ESWT adsorbent

\section{Discussion}

The chemical compositions of the calcinated eggshell (ESC), activated carbon (ESA) and powdered eggshell (ESWT) are shown in Table 1, 2, and 3 respectively. It showed that among the compositions in ESC, the proportions of oxygen has reduced by $4.05 \%$ and that of calcium has increased by $313.7 \%$ when compared in ESWT respectively. This showed the ease in the conversion of $\mathrm{CaCO}_{3}$ to $\mathrm{CaO}$. Thisfollowed a study reported by [1]. Similarly in ESA, the proportion of carbon has decreased to $33.57 \%$ when compared with ESWT. This is an indication of the difficulty in conversion of activated carbon. 
The porosity and surface area of the three adsorbents are shown in Fig. 1, 2, and 3 respectively. The porosity and surface area of ESC was found to be good for the adsorption of hydrogen sulfide, while the ESA and ESWT have less porosity and surface area for the adsorption of $\mathrm{H}_{2} \mathrm{~S}$.

\subsection{Removal kinetics of the adsorbents.}

\subsubsection{Effect of concentration of pollutants $\left(\mathrm{H}_{2} \mathrm{~S}\right)$ on adsorbents.}

The adsorption capacities of the ESA, ESA, and ESWT at $250 \mathrm{mg} / \mathrm{l}$ of the pollutants were $2.1 \mathrm{mg} . \mathrm{g}^{-1}, 1.6 \mathrm{mg} . \mathrm{g}^{-1}$ and $0.55 \mathrm{mg} . \mathrm{g}^{-1}$ as shown in shown in Fig. 7, 8 and 9 respectively. Their equilibrium times were 250, 350 and 400 minutes respectively. It showed an increase of adsorption capacities with increasing the concentration of pollutants and vice versa.

\section{Conclusions}

The present research studied on investigating the adsorption capacity of chicken waste eggshell as green and economic adsorbent for the removal of hydrogen sulfide from petroleum refinery. Using container experiments was different from the conventionally batch reactor experiments reported by [8].

The grounded chicken eggshell used in this study mainly composed of calcium carbonate $\left(\mathrm{CaCO}_{3}\right)$. There were no any toxic elements from all three adsorbent. It showed the ease of conversion of $\mathrm{CaCO}_{3}$ to $\mathrm{CaO}$ in the calcinate eggshell. Therefore, very suitable adsorbent for removal of the hydrogen sulfide. It was very difficult to be converted to calcium carbonate $\left(\mathrm{CaCO}_{3}\right)$ to the pure carbon in the activated carbon derived from eggshell. Therefore, less suitable adsorbent then the calcinate eggshell. However, the powdered of eggshell without treatment was the least suitable adsorbent due to the presence of variable constituent elements.

The container experiments of three adsorbents at $250 \mathrm{mg} \cdot 1^{-1}$ of the pollutants concentration indicated that the calcinate of eggshell has highest adsorption capacity of $2.1 \mathrm{mg}^{-1} \mathrm{~g}^{-1}$ and the equilibrium time was 250 minutes. The activated carbon derived from eggshell has the second highest adsorption capacity of $1.6 \mathrm{mg} . \mathrm{g}^{-1}$ and the equilibrium time was 350 minutes while the adsorption capacity of powdered eggshell without treatment was the less suitable of $0.55 \mathrm{mg} \cdot \mathrm{g}^{-1}$ and the equilibrium time was 400 minutes.

Thus, it is concluded that the chickens' eggshell are very useful green and economic adsorbents due to their availability and absence of any toxic and hazardous constituents' elements from all adsorbents the physically modified grounded chicken eggshell. Therefore, very suitable for the removal of $\mathrm{H}_{2} \mathrm{~S}$ from wasters with the calcinate modified been the most suitable then the activate carbon modified adsorbent.

ESC Calcinate of eggshell

\section{Nomenclatures}

$\begin{array}{lc}\text { ESA } & \text { Activate carbon of eggshell } \\ \mathrm{ESWT} & \text { Eggshell without treatment } \\ \mathrm{H}_{2} \mathrm{~S} & \text { Hydrogen sulfide } \\ \mathrm{FeS} & \text { ferrous sulfide } \\ \mathrm{HCl} & \text { Hydrochloric acid } \\ \mathrm{FeCl}_{2} & \text { Iron(II) chloride } \\ \mathrm{CaOC} \text { alcium oxide } & \\ \mathrm{CaCO}_{3} \text { Calcium carbonate } \\ \mathrm{Mg} & \text { Magnesium } \\ \mathrm{K} & \text { Potassium } \\ \mathrm{Mo} & \text { Molybdenum } \\ \mathrm{P} & \text { Phosphorus } \\ \mathrm{S} \mathrm{Sulfur} & \\ \mathrm{Cd} & \text { Cadmium }\end{array}$

\section{Acknowledgment}

Author is thankful to the twin ministries of Oil and the Higher Education of Iraq for supporting my study in Universiti Putra Malaysia.

\section{References}

[1] Abdulbaki , U. D., Ahmad, I. H., \& Maina, M. M. (2014). Quality Assessment of Groundwater around Opendumpsites in kano Northwesten Nigeria.IOSR international journal of Enviromental Science, Toxicology and Food Technology 8(9), 139-145.

[2] Asaoka, S., Yamamoto, T., Kondo, S., \& Hayakawa, S. (2009). Removal of hydrogen sulfide using crushed oyster shell from pore water to remediate organically enriched coastal marine sediments. Bioresource Technology, 100(18), 4127-4132.

[3] Haddadian, Z., Shavandi, M. A., Zainal, Z., Halim, M., \& Ismail, S. (2013). Removal Methyl Orange from Aqueous Solutions Using Dragon Fruit (Hylocereusundatus) Foliage. Chemical Science Transactions, 2(3), 900-910.

[4] Kumar, U., \& Bandyopadhyay, M. (2006). Sorption of cadmium from aqueous solution using pretreated rice husk. Bioresource Technology, 97(1), 104-9. 
[5] Kyzas, G. Z., \& Kostoglou, M. (2014). Green Adsorbents for Wastewaters: A Critical Review, (i), 333-364

[6] Malik, P. K. (2004). Dye removal from wastewater using activated carbon developed from sawdust: adsorption equilibrium and kinetics. Journal of Hazardous Materials, 113(1), 81-88.

[7] Tsai, W., Chen, H., Kuo, K., Lai, C., Su, T., Chang, Y., \& Yang, J. (2009). the adsorption of methylene blue from aqueous solution using waste aquacultural shell powders.Journal of Environmental Engineering Management,, 19(3), 165-172.

[8] Xiao, Y., Wang, S., Wu, D., \& Yuan, Q. (2008). Experimental and simulation study of hydrogen sulfide adsorption on impregnated activated carbon under anaerobic conditions. Journal of Hazardous Materials, 153(3), 1193-200. 